\title{
TEACHING ENGLISH FOR YOUNG LEARNERS THROUGH ICTS
}

\author{
Puspita Dewi \\ puspitadewi1191@gmail.com \\ Sekolah Tinggi Manajemen dan Informatika \\ (STMIK) Bumigora Mataram-NTB
}

\begin{abstract}
Nowdays, people throughout the world learn English and particularly English has important role in Indonesia, especially for facing free trade in ASEAN Economic Community (MEA). However, Teaching English as second language becomes more challenging to teach, particularly for young learners. In this case, Information and communication Technologies (ICTs) has a pivotal role in assisting teachers in teaching and learning English. Numerous scholars, educators and teachers believe that ICT has possitive effects in teaching and learning English. Through ICT by incorperating local cultures and values, it will make the activities in classroom to be more interactive and interesting. Language, cultures, and IT should be embedded and incorporated. Teachers can encourage the children's motivation and improve their English abilities through ICTs. This article reviews some theories of using ICTs by integrating the diversity of cultures and values either local or national and international cultures and values in teaching and learning process. It can assist teachers to establish their teaching and learning in classrooms to be more effective, interactive, and communicative.

Keywords: Information and communication Technologies (ICTs), young learners, local cultures and values
\end{abstract}

\section{INTRODUCTION}

ASEAN Economic Community (MEA) becomes a trigger for everyone to learn English. Because English as an international language is needed especially for people who want to get better jobs and future. Thereby, every adult and even young person learns English. Some universities are provided a special subject of English for Young Learners. The earlier someone learns languages, the more successful she/he will be. It based on the Critical Period Hypothesis (CPH) theories believed that children (estimated 2-13 years of age) are easier to learn foreign or second language. It is apparent that children are likely to acquire a second language more successful than older learners (Baker, 2010 cited in Lin, 2014). Some scholars believe that the earlier people learnlanguages, the easier they master about the language, particularly for pronuncation, people who learn English in young age, they are near to like native-speakers.

Language is a very complex and teachers have obligation to teach the complexity of the language becomes simpler and easier to be understood, especially for teaching English for young learners. Information and Communication Technology (ITC) can be applied in teaching and learning language. Most children enjoy internet, television, radio, youtube, or another mobile learning, particularly for learning English. ICT can play a crucial role in development of language or second language, in regarding to young people. Using ICT, the classroom will be more flexible and communicative. We can find many ways to attract students' motivation to learn English with 
technology involving internet, song, youtube, and other media. Utilizing the technology in teaching and learning process, cultures and other values can be imbeded. Because, learning English or other languages not only for mastering the language but also introducing the culture either the local culture or the cultureof other countries. In line to education goals as UNESCO noted that education is having the following aims (UNESCO, 2011):

1. Inculcating the community's core values and passing on its cultural legacy

2. Supporting the personal development of children, young people and adults

3. Promoting democracy and increasing participation in society, particularly among women and minorities

4. Encouraging cross-cultural understanding and the peaceful resolution of conflict, improving health and well-being

5. supporting economic development, reducing poverty and increasing widespread prosperity.

\section{SECOND LANGUAGE ACQUISITION}

Language is a very complex system of human in which there are some components or functions of the language including syntax, morphology, phonology, semantics, phonology, and pragmatics. Students should master all the components in order to they are skilful and master four of the skills (listening, speaking, reading, and writing). Those of components are described by Owens, (1982). Before people produce words or sentences, those patterns of sentences are processed in neuron or mind. It relates to Steinberg, Hiroshi, \& David (2001) claimed that 'speech comprehension is the basis for the construction of a grammar in the mind' and Fromkin, et.al (1990:) emphasized that "when we speak, we access this grammar to find the words, construct novel sentences, and produce the sounds that express the message we wish to convey and when we listen to someone speaking, we also access the grammar to process the utterance in order to assign a meaning to the sounds we hear." The processes of acquiring and producing language are very complex.

Process of acquisition became controversial among psycholinguists, such as Noam Chomsky, B.F Skinner, Edward Sapir, Bloom Field, and other experts. Language acquisition actually is Language Acquisition Development (LAD) called Universal Grammar (UG) that proposed by Chomsky. He believed that language is formalistic mechanism (a generative grammar) in which it distinguished between grammatical pattern and non-grammatical pattern. However, behaviorism did not belong (reject) to Chomsky's perspective. Behaviorism claimed those human beings born are like papers; empty space without any squiggle or called tabula rasa. It means that language acquisition development is determined by environment. We are very appreciating to those differences that proposed between scholars; Chomsky states that language acquisition is based on nature, but Skinner in his behaviorism perspective believes that language acquisition has characteristic as nurture. The explanation more detail between the terms nature and nurture are discussed by Dardjowidjojo (2003).

Spolsky \& Hult (2008) discuss the process of second language acquisition. They state that sentences will process in the brain (mental grammar or mental lexicon) before people produce sentences. Language also relates to the brain mechanism, such as cortex, cerebrum, parietal lobe, hemisphere, and the other part of the brain that is one of the principle aspects in processing the language. Languages, sentences, or even words are constructed by our mind because language relates to cognition or mental process (Isacc \& Reiss, 2008:); this topic has been discussed and 
written in many books (Steinberg, et.al.,2001; Fromkin, et.al 1988; Arifuddin, 2010; \& Steinberg, 1982). It means that the language processes (productive/receptive) are constructed by minds. Language child's development depends on social (environment) and his/her psychology. Gregory (2008) notes a concept of Vygotsky that:

"Any function in the child's development appears twice, or on two planes. First it appears on the social plane, and then on the psychological plane. First it appears between people as an interpsychological category, and then within the child as an intrapsychological category. This is equally true with regard to voluntary attention, logical memory, the formation of concepts, and the development of volition." (Vygotsky, 1981).

Steinberg, Hiroshi, \& Davidalso (2001) give a discription more detail of intellectual processing in acquire second language. They believe that there are two ways to learn syntax of second language: explication and induction. The explication is the process whereby the rules and structures of the second language are explained and taught to the learners but explication is rarely applicable to young children by the age of 4-5 years. For instance, parents will not tell their children that to make the plural of "dog" you add sound " $z$ " but the word "duck" has unvoiced one "s" or parents will not tell their children that there is a Subject + Verb + Object ordering in sentences.

Induction is defined by learning rules by self-discovery to acquire second languages. Steinberg, Hiroshi, \& David (2001) give explanation and example of what induction is. Those scholars state that the children who is exposed to second-language speech and members what they have heard will be able to analyze and discover the generalization or rules that underlines in the speech. For instance, given the sentences "John danced then John Sang" and "John danced then he sang", these two examples, the learner can determine the two of sentences are related, with 'he' being replacement for 'John'. The second-language learners will always be trying to discover and figure out language by induction. The learners can acquire and learn the second-language by themselves from their environments.

\section{THE TEACHING ENGLISH FOR YOUNG LEARNERS}

Language development among the learners will be different, depended on age, cognitive, social, and motivation. The second-language learning success is influenced by those factors, in particular, one of the main factors is age. The enthusiasm of the quotation "the younger, the better" and CPH theory becomes reference for scholars, educators, teachers, or other stakeholders to propose second language especially English to be taught earlier. There are several advantages of an early start (Paradis, 2004; Johnstone, 2009 as cited in Damar, Gursoy, \& Korkmaz, 2013):

1. Young learners acquire languages with greater ease, especially the sound system, and develop implicit competence since they can rely on natural acquisition processes.

2. They are undeniably better at acquiring the sounds and rhythms of the target language. Then, they have lower affective filter than older learners do and they are also more intuitive and less anxious.

3. Moreover, they have more time to learn the target language and larger capacity to gain awareness about the potential intercultural identity. 
The aims of teaching English for young learners are not merely for giving input of the language itself but also for giving them knowledge of their potential cultural identity. It is better to introduce the culture (local culture) and other cultures to young people in order to their awareness of local cultures and other districts and countries' cultures appear earlier. The earlier they know the culture, the better they aware of their identity. To promote their culture and encourage their motivation in learning English, the teachers can utilize technologies. Various technologies that are used for facilitating communication such as Cellular Phones, radio, video, television, computers, and satellite systems among others (Sharndama, 2013: 34) and television becomes increasingly interested in people everyday life and relationship (Hartley, 1999: 8). Many scholars and educators believe that ICT can encourage students to be more creative, communicative, and motivated. It is very useful and helpful in teaching and learning language. Incorperating local, national, and international cultures and values with ICT will be more effective and communicative. Morever, now children always use internet, HP, computer, and the others to find information in their daily life.

\section{ICTS BY INCORPERATING CULTURES IN TEACHING AND LEARNING ENGLISH}

English as a foreign language in Indonesia has a big role because English as an international language becomes a trigger for every country to learn the language. Teaching English becomes more challenging for teachers because young people now are more creative and up to date. If the teachers apply and use traditional method and media in classroom, it will be boring. Thereby, teachers need to identify and find out other ways to elicit the students' motivation and interaction in classroom. Information and Communication Technology (ICT) become one of the solutions to attract and motivate young learners. Because ITC including computers, internet, Cellular Phones, radio, video, television, computers, and satellite systems ( $\mathrm{Fu}, 2013$; Sharndama, 2013) widely used in various aspects involving education. Lafferiere also states that ICT in schools and classrooms tends to attract learner's interest and motivation (Kaffash, et.al, 2010). Based on the research, Florish (2014) stated that ICT has the potential important role in supporting and enhancing of learning language. Related to her interview with Dr.A. Gunawan Jati, a senior lecturer at Faculty of Arts and Design of Bandung Institute of Technolory (ITB), he stated that ICT, including the Internet, wireless networks, cell phones, and other communication mediums, has become very essential in teaching and learning language and it creates a classroom to be more interesting.

ICT also can elicit students' creativity and profeciency related to their knowledge and cultureseither local cultures or national and international cultures. "ICT provides productive teaching and learning in order to increase people's creativity and intellectual resources especially in today's information society"(Aduwa-Ogiegbaen and Iyamu, 2005)."The word 'culture' itself now appears in so many contexts and indeed 'culture' almost replaces 'context' in much discourse in education and social sciences” (Alred, Byram, \& Fleming, 2013). The materials are imbeded with local cultures, national and international cultures and values by utilizing the ICT. Teaching and learning process and the materials that incorperated by cultures will be more effective and contextual.Johnson stated that Education, several challenges for teacher education including English teachers. He mentioned one of the first challenge is "to recognize that both the content and activities of L2 teacher education must take into account the social, political, economic, and cultural histories that are located in the contexts where L2 teachers live, learn, and work". It means that the materials or activities should be based on their environment and 
based on the contexts of the students' cultures and values and introduce other cultures in order to they can compare, learn, and respect to other people's culture.

Hutchinson and Waters which is similar to Richards and Renandya (2002: 80-89) stated that the effective teaching materials must be contextualized; language development requires learners engagement in purposeful use of language; the language used should be realistic and authentic; classroom materials will usually seek to include an audio visual component; second language learners need to develop the ability to deal with the written as well as spoken genres; teaching materials foster learner autonomy; materials need to be flexible enough to cater to individual and contextual differences; and learning needs to engage learner both affectively and cognitively.

The students learn English in order to able to use the language in their daily life. The goals in learning language are not only the students be able to use the language but also understand about the culture and values. Both of the aspects should be imbeded in teaching and learning to encourage and motivate the student to know deeply of their cultures and culture of other countries. The input (materials) should be based on their environment, the issues or the topics should be based on the conditions or issues arround them called authentic. An authentic input, particularly written and spoken, the materials should relate to inside classroom and the real world outside the classroom.

Brosnan et.al, 1984 (in Nunan, 2004) offer the justifications for the use of the real-world recourses:

1. The language is natural.

2. It offers the students the chance to deal with small amounts of the print which, at the same time, contain complete meaningful messages.

3. It provides students with the opportunity to make use of non-linguistics clues (layout, pictures, colours, symbols, the physical setting in which it occurs) and so more easily to arrive at meaning from the printed word.

4. Students need to be able to see the immediate relevance of what they do in the classroom to what they need to do outside it, and real-life reading material treated realistically makes the connection obvious.

To create the classroom becomes in real life, we need to provide variety of activities from the real world outside the classroom. Using ICT we can create interesting of various activities that are like the real world outside the classroom, such as showing videos, watching youtube, listening music, providing pictures, and the others. Internet, television, radio, and another mobile learning provide many materials and meaningful information of cultures through out the world. Because language, culture, and technology cannot be separated. Those are like a coin that gives influencesone and another..As mentioned by McKay (2003, as cited in Khairuddin, Shukri, \& Sani, 2014), it common practices that the culture of the native speaker is integrated into the classroom teaching materials to teach the English language in which this is recommended by Kachru which assumes that the understanding of learning language will be more successful. Diversity cultures should be taught by teachers as mentioned by Department of Education and Science Guidelines on Traveller Education in Primary Schools (2002 cited Guideline for school) notes that "young people should be enable to appreciate the richness of a diversity of culture and be supported in practical ways to recognize and challenge prejudice and discrimination where they exist".In conclusion, it is better to incorporate the ICTs in teaching and learning language. 


\section{CLASSROOM MANAGEMENT}

Every teacher has different ways to attract the students' attention and motivation to learn English. There are several factors that influence the success or failure in learning second language, such as students, teachers, methods, media, activities and materials. Classroom management is one of the most important roles in teaching and learnig success and it is one of the main ways in order to achieve the goal of teaching."Classroom management is defined as a wide range of teachers' efforts to supervise students' learning activities, social interactions, and behaviours" (Brophy, 1988; Burden, 2005; Good \& Brophy, 2003; Wolfgang \& Glickman, 1986 cited in Kazemi \& Soleimani, 2016). However it becomes a big question is how to manage the classroom and how the goals of the study can be achieved?

The classroom management is one of a pivotal role in motivating the students. We can adapt and modifiy the classroom management from the theory that is porposed by Searle's taxonomy (Holtgraves, 2008:14). Actually there are five points proposed by Searle but in this case, the writer merely takes 3 points:

Table 1. Taxonomy of Illocutionary Points

\begin{tabular}{l|l|l|}
\hline Illocutionary Point & Direction of Fit & Examples \\
\hline Directive & World-to-words & Request, order \\
\hline Assertive & Words-to-world & Conclude, predict \\
\hline Declarative & $\begin{array}{l}\text { World-to-words and words- } \\
\text { to-world }\end{array}$ & Declare war, marriage \\
& & \\
\hline
\end{tabular}

Based onTable 1 shows that directive (world-to-words) can be applied to create some activities in teaching and learning language, for example, the teachers can show some phenomena, pictures, or videos related to the current situation in the world, then the students will create assumption or their opinion about the pictures or videos orally.It means that, implicitly the teachers give stimulation to the students to think and to speak.Pictures or videos can stimulate and help the students to think creatively. The second point is assertive (words-to-world) in which teachers provide some words in the slide and instruct the students to make questions to their friends or lecturer based on the words. From the the words they can make conversations. Afterward, ask the students of the current issues of their life and the issues relevant to the topic that the students learn.It can assist them to create their own sentences and their own world. The last point, declarative (world-to-words and words-to-world) is the combination between directive and assertive.

The three points of Searle's taxonomy can be applied by utilizing ICT. Several ways can be applied to manage the classroom through ICTs:

1. Provide some slides in the classroom and explain to the students the materials using the slide.

2. Show some pictures to the students to elicit them and motivate them to speak.

3. Ask the students to watch a video related to the topic that we learn and ask them "what do you think about the video".

4. Discuss with the students about English materials or currents issues of English as second language (foreign language) via watsup, bbm, line, and the others.

5. Give additional materials to the students through email. 
6. The students can submit their assignments through email and give them feedback by email. Interaction can be built from the email, line, watsap, and the others.

7. Provide songs, play the music and ask them to gist what the content of the song. The teachers also can ask the students to fill the missing lyric based on the song.

By using ICT, it is effective to be applied either insmall classrooms or in large classrooms. ICT can assist both the teachers or students to be more economist because it is paperless. It also can help the teachers to build a good interaction with the students. Finally, by using ICT, the teaching and learning process becomes more interesting and communicative.

\section{CONCLUSION}

One of the biggest challengings in facing ASEAN Economic Community (MEA) is language, especially for local people (Indonesia people). English as an international language should be mastered by people who want to get better jobs, because Indonesia people will compete with plenty people from other countries. Thereby, most parents nowadays push their children to learn English to prepare them to get a good job in the future. Then, the task for the teachers to teach young people learners is how to teach them not only about the language but also the cultures imbeded to the teaching and learning language.

Language and cultures cannot be separated each other because when we learn language the culture is imbeded. To facilitate those elements covered in teaching and learning English, ICT has a big role. ICT also has a pivotal role to encourage the students' motivation in learning English. Some scholars believe that using ICT has a positive effect to teaching and learning English and also for the students' motivation.

\section{REFERENCES}

Aduwa-Ogiegbaen, S. E., \&Iyamu, E. O. S. (2005). Using Information and Communication Technology in Secondary Schools in Nigeria: Problems and Prospects. Educational Technology \& Society, 8 (1), 104-112.

Alred, G., Byram, M. \& Fleming, M. (2003). Intercultural experience and education. . In Alred, G., Byram, M. \& Fleming, M.(Ed). Frankfurt Lodge: Cromwell Press..

Arifuddin.(2010). Neuropsikolinguistik.Mataram: RajawaliPersDivisiBuku

Damar, E.A., Gursoy.E., \& Korkmaz. S.C. (2013). Teaching English to young learners: Through the eyea of EFL teacher trainers. International Association of Research in Foreign Language Education and Applied Linguistics. (2)3, 95-110.

Dardjowidjojo, Soenjono. (2003). Psikolinguistik: Pengantar Pemahaman Bahasa Manusia, Jakarta: Yayasan Obor Indonesia

Deparment of Education and Science. (2002). Guideline on traveller education in primary schools.

Floris,F.D. (2014). Using information and communication technology (ICT) to enhance language teaching \& leanring: An interview with Dr. S. Gumawang Jati. TEFLIN Journal. 25,139-146.

Fromkin, V., et. al. (1990). An Introduction to language: Second Australia edition. Marrickville: Holt, Rinehart, and Winston.

Fu, J.S. (2013). ICT in education: A critical literature review and its implications. International Journal of Education and Development using Information and Communication Technology (IJEDICT), 9, 112-125.

Gregory, E. (2008). Learning to read in a new language. London: Sage Publication. 
Hartley, P. (1999). Interpersonal communication. (2nd Ed). New York: Routledge. perguruanTinggi PT Raja Grafindo Persada.

Holtgraves, T.M. (2002). Language as social action: social pyschology and language use. New Jersey: Lawrence Erlbaum Associates. This edition published in the Tylor \& Francis eLibrary.2008.

Isac, D., \& Reiss, C. (2008).I-Language: An introduction to linguistics as cognitive science. New York: Oxford University Press.

Johnson, K.E. (2009). Second language teacher education: A social perspective. Oxon. New York: Routledge.

Kaffash, H.R. \& Zohreh. (2010). A close look in to role of ICT in education.Journal of Instruction. 3, 63-82.

Kazemi, Y. \& Soleimani, N. (2016). On the relationship between EFL teachers' classroom management approaches and the dominant teaching stle: A mixed method study. Iranian Journal of Language Teaching Research. 4(2). 87-103.

Khairuddin, Z., Shukry, A.S.M., \& Sani, N.A. (2014). Reading trends andperceptions towards Islamic English websites as teaching materials. CanadianCenter of Science and Education, 7, 124-133.

Liang \& Chen Lin. (2014). The role of linguistics in second language classrooms.American International Journal of Contemporary Research, 4, 42-47.

McKay, S.,L. (2003). Toward an appropriate EIL pedagogy: re-examining common ELT assumptions. International Journal of Applied Linguistics, Vol. 13. No. 1.

Nunan. (2004). Task-based language teaching. Cambridge: Cambridge University Press.

Owens, R. E. (1982). Language development: An introduction. New York: Macmillan Publishing Company.

Richards, J. C., \& Renandya, W. A. (2002). Methodology in language teaching: An anthology of current practice. Cambridge: Cambridge University Press.

Sharndama, E.C. (2013). Application of ICTs in Teaching English (ELT) in Large Classes. Federal University Wukari, Faculty of Humanities, Management and Social Sciences, Department of English and Literary Studies., Taraba State Nigeria. Available online July 2013. Pages 34-39.

Steinberg, D.D,. Hiroshi N, David P.A. (2001). Psycholinguistics: Language, mind, and word. London: Longman.

Spolsky, B \&Hult, F.R. 2008.The Handbook of Educational Linguistics. Australia: Blackwell Publishing.

UNESCO. UNESCO ICT competency framework for teachers. UNESCO and Microsoft 2011. 